DOI 10.22460/jpmi.v1i3.427-434

\title{
ANALISIS KEMAMPUAN BERPIKIR KRITIS MATEMATIK SISWA SMP PADA MATERI SEGITIGA DENGAN PENDEKATAN METAPHORICAL THINKING
}

\author{
Dina Oktoviani Mardiyanti ${ }^{1}$, M. Afrilianto ${ }^{2}$, Euis Eti Rohaeti ${ }^{3}$ \\ 1,2,3 IKIP Siliwangi, Jl. Terusan Jenderal Sudirman, Cimahi, Jawa Barat, Indonesia \\ 1dinamardiyanti19@gmail.com, ${ }^{2}$ muhammadafrilianto1@ikipsiliwangi.ac.id, \\ 3e2rht@ikipsiliwangi.ac.id
}

Diterima: 22 April 2018; Disetujui: 28 Mei 2018

\begin{abstract}
This research is based on facts in schools on implementing Kurtilas, students are demanded to think more scientific. Kurtilas is concerned about critical thinking skill of mathematics for solving problems. To gain increased on critical thinking skill of Mathematics, the researcher used Metaphorical Thinking by Deskriptif Kualitatif method. This research was conducted at SMPN 22 Depok and used VII grade as the research samples. The qualitative data was gained from trying out the result of students critical thinking skill of mathematics. The research result shows that Metaphorical Thinking Approach can increase critical thinking skill of mathematics of junior high school students on the triangular material.
\end{abstract}

Keywords: Metaphorical Thinking Approach, Mathematical Critical Thinking, Triangular

\begin{abstract}
Abstrak
Penelitian ini dilatarbelakangi oleh fakta di sekolah dalam penerapan Kurikulum 2013 (Kurtilas), siswa lebih dituntut untuk berpikir saintis. Kurikulum 2013 menitikberatkan kemampuan berpikir kritis matematik untuk pemecahan masalah. Untuk memperoleh peningkatan kemampuan berpikir kritis matematik, peneliti menggunakan pendekatan Metaphorical Thinking dengan metode Deskriptif kualitatif. Penelitian ini diadakan di SMPN 22 Depok dan menggunakan kelas VII sebagai sampel penelitian. Data kualitatif diperoleh dari hasil uji coba soal kemampuan berpikir kritis matematik siswa. Hasil penelitian menunjukkan bahwa pendekatan Metaphorical Thinking dapat meningkatkan kemampuan berpikir kritis matematik siswa SMP pada materi segitiga.
\end{abstract}

Kata Kunci: Pendekatan Metaphorical Thinking, Berpikir Kritis Matematis, Segitiga

How to cite: Mardiyanti, D. O., Afrilianto, M., \& Rohaeti, E. E. (2018). Analisis Kemampuan Berpikir Kritis Matematik Siswa SMP pada Materi Segitiga dengan Pendekatan Metaphorical Thinking. JPMI - Jurnal Pembelajaran Matematika Inovatif, 1 (3), 247-434.

\section{PENDAHULUAN}

Pendidikan Nasional berfungsi mengembangkan kemampuan dan membentuk watak serta peradaban bangsa yang bermartabat dalam rangka mencerdaskan kehidupan bangsa, bertujuan untuk mengembangkan potensi peserta didik agar menjadi manusia yang beriman dan bertakwa kepada Tuhan Yang Maha Esa, berakhlak mulia, sehat, berilmu, cakap, kreatif, mandiri dan menjadi warga Negara yang demokratis serta bertanggung jawab (UU Republik Indonesia Pasal 20 tahun 2003 tentang Sistem Pendidikan Nasional). 
Dalam Kurikulum 2013, siswa lebih dituntut untuk berpikir saintis dengan menitikberatkan kemampuan berpikir kritis matematik untuk pemecahan masalah. Siswa dibingkai dalam pengerjaan penelusuran konsep-konsep Matematika yang seringkali berbentuk soal uraian dan mampu menemukan sendiri penguasaannya. Oleh karenanya siswa banyak mengeksplorasi kemampuan dalam cara berpikir mandiri maupun berkelompok atau dengan kata lain pengaplikasian dalam ranah kooperatif.

Berpikir itu sendiri menurut Ahmadi (2016) bukanlah merupakan peristiwa yang terjadi secara tiba-tiba. Untuk mengembangkan kemampuan Matematika tersebut dipilih salah satu kemampuan yang dapat merangsang anak berpikir tingkat tinggi, salah satu kemampuan tersebut adalah kemampuan berpikir kritis. Masalah dalam pembelajaran Matematika di SMP saat ini adalah kurang tepatnya pendekatan pembelajaran yang digunakan guru dan masih rendahnya kemampuan siswa dalam menyelesaikan soal Matematika terutama soal yang berbentuk uraian bermetafora yang lebih menekankan pada penguasaan konsep dan berpikir kritis (Hendriana, Rohaeti, \& Hidayat, 2017; Hendriana, Hidayat, \& Ristiana, 2018; Hidayat, 2011; 2012; Sumarmo, Hidayat, Zukarnaen, Hamidah, \& Sariningsih, 2012; Tresnawati, Hidayat, \& Rohaeti, 2017).

Matematika dengan hakikatnya sebagai ilmu yang terstruktur dan sistematis, serta mengembangkan sikap berpikir kritis, objektif, dan terbuka. Maka dari itu, mengembangkan kemampuan berpikir kritis dalam pembelajaran Matematika sangatlah penting. Selain itu, Matematika juga dapat mengembangkan kemampuan pemecahan masalah.

Salah satu materi pembelajaran yang menggunakan kemampuan tingkat tinggi adalah materi geometri. Hvidsten (Noto, 2015) menyatakan bahwa geometri merupakan satu bagian yang paling kaya dalam eksplorasi Matematika. Aspek-aspek visual pada geometri menjadikan eksplorasi dan eksperimentasi alami dan intuitif. Di sisi lain, abtraksi-abstraksi yang dikembangkan untuk menjelaskan pola dan hubungan geometri menjadikan geometri sebagai subyek yang sangat penting dan dapat diterapkan pada bermacam-macam situasi.

Dalam pembelajaran geometri diajarkan berbagai bentuk bangun sebagai pencerminan dari bangun yang ada dalam kehidupan nyata. Dari bentuk tersebut siswa mengolahnya sehingga dapat memunculkan kemampuan berpikir kritis matematik.

Atas dasar pemikiran tersebut, peneliti melakukan penelitian dengan judul "Analisis Kemampuan Berpikir Kritis Matematik Siswa SMP pada Materi Segitiga dengan Pendekatan Metaphorical Thinking”. Berdasarkan latar belakang di atas, maka masalah yang dikaji dalam penelitian ini adalah:

a. Apakah peningkatan kemampuan berpikir kritis matematik siswa dengan pendekatan Metaphorical Thinking lebih baik daripada siswa yang menggunakan pembelajaran biasa?

b. Apa saja kesulitan siswa dalam menyelesaikan soal-soal kemampuan berpikir kritis matematik?

\section{Kemampuan Berpikir Kritis Matematik}

Kemampuan berpikir kritis matematik menurut Ennis (Lestari dan Yudhanegara, 2015) adalah kemampuan berpikir dalam menyelesaikan masalah Matematika yang melibatkan pengetahuan Matematika, dan pembuktian Matematika. Gokhale (Hendriana \& Soemarmo, 
2014) mendefinisikan soal berpikir kritis adalah soal yang melibatkan analisis, sintesis, dan evaluasi dari suatu konsep.

Glaser (Sumaryati \& Sumarmo, 2013; Sumarmo, Hidayat, Zulkarnaen, Hamidah, Sariningsih, 2012) menyatakan bahwa berpikir kritis matematis memuat kemampuan dan disposisi yang dikombinasikan dengan pengetahuan, kemampuan penalaran matematika, dan strategi kognitif yang sebelumnya untuk menggeneralisasikan, membuktikan, mengakses situasi matematik secara reflektif.

Indikator kemampuan berpikir kritis matematik menurut Ennis (Hendriana \& Soemarmo, 2014; Lestari \& Yudhanegara, 2015) adalah sebagai berikut: a) Memberikan penjelasan sederhana (elementary clarification). Siswa memfokuskan diri pada pertanyaan, menganalisis dan mengklarifikasi pertanyaan, jawaban dan argumen, mempertimbangkan sumber yang dapat dipercaya; b) Membangun keterampilan dasar (basic suport). Siswa mengamati dan menganalisis deduksi, menginduksi dan menganalisis induksi; c) Membuat simpulan (inference). Siswa merumuskan eksplanatori, kesimpulan dan hipotesis; d) Membuat penjelasan lebih lanjut (advance clarification). Siswa menarik pertimbangan yang bernilai; e) Menemukan strategi dan taktik (strategy and tactis) untuk menyelesaikan masalah.Siswa menetapkan suatu aksi, dan berinteraksi dengan orang lain.

\section{Pendekatan Metaphorical Thinking}

Pendekatan Metaphorical Thinking (berpikir metapora) adalah kemampuan memodelkan suatu situasi matematis yang dimaknai dari sudut pandang semantik menggunakan metafora. Menurut Holyoak \& Thagard (Hendriana, 2012), metafora berawal dari suatu konsep yang diketahui siswa menuju konsep lain yang belum diketahui atau sedang dipelajari siswa. Sedangkan menurut Carreira (Afrilianto, 2012), konsep berfikir yang menekankan pada kemampuan menghubungkan ide matematika dan fenomena yang ada diantaranya adalah Metaphorical Thinking.

Metaphorical thinking melalui tiga tahapan, antara lain (1) Grounding methapors merupakan dasar untuk memahami ide-ide matematika yang dihubungkan dengan pengalaman sehari-hari (2) Linking methapors: membangun keterkaitan antara dua hal yaitu memilih, menegaskan, memberi kebebasan, dan mengorganisasikan karakteristik dari topik utama dengan didukung oleh topik tambahan dalam bentuk pernyataan-pernyataan metaforik (3) Redefinitional methapors: Mendefinisikan kembali metafor-metafor tersebut dan memilih yang paling cocok dengan topik yang akan diajarkan.

\section{METODE}

Studi ini adalah deskriptif kualitatif dengan desain kelompok experiment menggunakan pretes dan postes serta bertujuan menelaah peranan peningkatan kemampuan berpikir kritis matematik siswa. Populasi dalam penelitian ini adalah 20 siswa (12 putri dan 8 putra) kelas VII SMPN 22 Depok.

Instrumen dalam penelitian ini berupa seperangkat tes kemampuan berpikir kritis matematik yang terdiri dari 10 butir soal uraian yang diambil dari berbagai sumber. Secara garis besar, penelitian dilakukan melalui tiga tahapan, yaitu: 1) persiapan, 2) Pelaksanaan, 3) evaluasi.

Instrumen dalam penelitian ini berupa seperangkat tes kemampuan berpikir kritis matematik yang terdiri dari 5 butir soal uraian yang diambil dari berbagai sumber. Kriteria penskoran 
untuk tes kemampuan berpikir kritis diberi nilai 0, 1, 2, 3, dan 4. Kemudian total skor dikalikan dengan 5, hingga skor maksimal adalah 100. Persoalan yang diberikan dengan mempertimbangkan kemampuan berpikir kritis matematik.

Tabel 1. Kriteria Pedoman Penilaian Kemampuan Berpikir Kritis Matematik

\begin{tabular}{|c|c|c|c|}
\hline \multirow[b]{2}{*}{$\begin{array}{c}\text { Indikator Kemampuan Berpikir Kritis } \\
\text { yang Diukur }\end{array}$} & \multicolumn{3}{|c|}{ Klasifikasi Jawaban Siswa } \\
\hline & $\begin{array}{c}\text { Tidak } \\
\text { Menjawab }\end{array}$ & $\begin{array}{c}\text { Kurang } \\
\text { tepat }\end{array}$ & $\begin{array}{c}\text { Menjawab } \\
\text { Tepat }\end{array}$ \\
\hline $\begin{array}{l}\text { Memberikan penjelasan sederhana } \\
\text { (Elementary Clarification) }\end{array}$ & \multirow{5}{*}{ Skor $=0$} & \multirow{5}{*}{$0<$ Skor $<4$} & \multirow{5}{*}{ Skor $=4$} \\
\hline $\begin{array}{l}\text { Membangun keterampilan dasar (Basic } \\
\text { Support) }\end{array}$ & & & \\
\hline Menyimpulkan (Inference) & & & \\
\hline $\begin{array}{l}\text { Membuat penjelasan lebih lanjut } \\
\text { (Advanced Clarification) }\end{array}$ & & & \\
\hline $\begin{array}{l}\text { Menyusun Strategi dan Taktik } \\
\text { (Strategies and Tactics) }\end{array}$ & & & \\
\hline
\end{tabular}

\section{HASIL DAN PEMBAHASAN}

\section{Hasil}

Ennis (Lestari dan Yudhanegara, 2015) menyebutkan kemampuan berpikir kritis adalah kemampuan berpikir dalam menyelesaikan masalah matematika yang melibatkan pengetahuan matematika, dan pembuktian matematika. Gokhale (Hendriana dan Soemarmo, 2014) mendefinisikan soal berpikir kritis adalah soal yang melibatkan analisis, sintesis, dan evaluasi dari suatu konsep.

Fakta di lapangan, dari 20 siswa yang mengerjakan uji coba soal pretes didapati persentase data sebagai berikut:

Tabel 2. Hasil Uji Coba Soal Pretes Kemampuan Berpikir Kritis

\begin{tabular}{ccc}
\hline KETUNTASAN & JUMLAH & PERSENTASE \\
\hline Tuntas & 8 & $40 \%$ \\
Tidak Tuntas & 12 & $60 \%$ \\
Jumlah & 20 & $100 \%$ \\
\hline
\end{tabular}

Setelah diadakan penelitian lebih lanjut dengan melakukan pendekatan Metaphorical Thinking selama 3 minggu, dilakukan uji coba postes dan diperoleh persentase data yang disajikan pada Tabel 3 berikut. 
Tabel 3. Hasil Uji Coba Soal Pretes Kemampuan Berpikir Kritis

\begin{tabular}{ccc}
\hline KETUNTASAN & JUMLAH & PERSENTASE \\
\hline Tuntas & 14 & $70 \%$ \\
Tidak Tuntas & 6 & $30 \%$ \\
Jumlah & 20 & $100 \%$ \\
\hline
\end{tabular}

Sesuai KKM (Kriteria Ketuntasan Minimal) yang ditetapkan di SMPN 22 Depok untuk Matematika adalah 75, maka setelah diadakan penelitian tercapai $70 \%$ siswa yang mencapai KKM dan 30\% masih di bawah KKM. Berdasarkan data tabel 2 dan 3 terlihat peningkatan ketuntasan kemampuan berpikir kritis matematik siswa setelah menggunakan pendekatan Metaphorival Thinking sebesar 30\%.

\section{Pembahasan}

Indikator kemampuan berpikir kritis matematis yang diukur pada penelitian ini terdiri atas lima indikator yaitu (1) memberikan penjelasan sederhana (elementary clarification); (2) membangun keterampilan dasar (basic support); (3) menyimpulkan (inference); (4) membuat penjelasan lebih lanjut (advanced clarification); dan (5) menyusun strategi dan taktik (strategies and tactics) (Lestari, 2014).

Materi yang diujikan pada tes kemampuan berpikir kritis matematik adalah materi segitiga mengenai phytagoras, perbandingan sudut dan panjang sisi. Dalam soal kemampuan berpikir kritis yang menggunakan metapora, bangun segitiga dapat dimisalkan dengan panjang lintasan berbentuk segitiga, atap bangunan berbentuk segitiga, dan ketinggian layang-layang saat diterbangkan.

Berikut ini merupakan permasalahan-permasalahan pada materi tersebut yang diujikan dalam tes kemampuan berpikir kritis matematik siswa:

a. Soal nomor 3

Sebuah taman berbentuk persegi akan dibuat kolam ditengahnya dengan tiga sudut dan tiga sisi dengan jarak tepi taman ke sudut kolam adalah 1 meter, sedangkan panjang taman adalah 12 meter. Berapa luas kolam tersebut?

\section{Analisis:}

12 siswa belum dapat memenuhi indikator (2) membangun keterampilan dasar (basic support) seperti menggambarkan soal yang diminta; (3) menyimpulkan (inference); (4) membuat penjelasan lebih lanjut (advanced clarification); dan (5) menyusun strategi dan taktik (strategies and tactics).

Mereka miskonsepsi indikator (3) dan (4) yaitu dengan mengurangi luas taman dengan segitiga padahal segitiga tersebut adalah kolam yang akan dicari luasnya, ada pula yang tidak mengurangi panjang kolam dengan jarak tepi taman. Sedangkan untuk indikator (5) sebaiknya untuk soal ini lebih diperjelas dengan gambar. 
b. Soal nomor 4

Sebidang tanah membentuk sudut $X, Y$, dan $Z$ dengan sudut $Y=60^{\circ}$, dan $X: Z=3: 5$. Uraikan cara mencari besar sudut $X$ dan $Z$.

\section{Analisis:}

4 siswa belum dapat memenuhi indikator (3) menyimpulkan (inference); (4) membuat penjelasan lebih lanjut (advanced clarification); dan (5) menyusun strategi dan taktik (strategies and tactics). Kurangnya siswa pada indikator (3) dan (4) yaitu siswa tahu bahwa jumlah sudut dalam segitiga adalah $180^{\circ}$ akan tetapi saat menjawab soal mereka hanya berfokus pada sudut $\mathrm{Y}=60^{\circ}$, sehingga mengkalikan perbandingan sudut $\mathrm{X}$ dan $\mathrm{Z}$ dengan $60^{\circ}$ bukan dengan $120^{\circ}\left(180^{\circ}-60^{\circ}\right)$. Sedangkan untuk indikator (5) sebaiknya diadakan peer tutor (dipasangkan dengan yang sudah bisa untuk membantu memecahkan soal).

2 siswa belum dapat memenuhi indikator (4) membuat penjelasan lebih lanjut (advanced clarification); dan (5) menyusun strategi dan taktik (strategies and tactics). Siswa tersebut dapat membuat perbandingan dengan baik, namun saat meneruskan jawaban salah dalam menghitung hasilnya. Untuk indikator (5) perlu dibutuhkan ketelitian dan pengecekan kembali jawaban.

c. Soal nomor 5

Sebuah kapal laut bergerak dari timur ke barat sejauh $2 x$ meter, kemudian berbelok kearah selatan sejauh $(x+5)$ meter. Jarak lintasan dari titik keberangkatan sampai titik tujuan adalah $(4 x+5)$ meter. Jika keliling lintasan adalah 59 meter. Uraikan cara menentukan panjang masingmasing lintasan.

\section{Analisis:}

6 siswa belum dapat memenuhi indikator (2) membangun keterampilan dasar (basic support) seperti menggambarkan soal yang diminta; (3) menyimpulkan (inference); (4) membuat penjelasan lebih lanjut (advanced clarification); dan (5) menyusun strategi dan taktik (strategies and tactics). Siswa tersebut bingung menentukan memakai cara apa untuk menjawab soal tersebut. Padahal seharusnya soal tersebut menggunakan rumus keliling segitiga yang digabungkan dengan Persamaan Linier Satu Variabel (PLSV).

2 siswa belum dapat memenuhi indikator (4) membuat penjelasan lebih lanjut (advanced clarification); dan (5) menyusun strategi dan taktik (strategies and tactics). Siswa tersebut hanya mengerjakan sebagian uraian cara penyelesaian jawaban.

Rendahnya kemampuan membangun keterampilan dasar (basic support), menyimpulkan (inference), dan membuat penjelasan lebih lanjut (advanced clarification) mengindikasikan bahwa siswa masih kesulitan dalam memecahkan masalah yang memerlukan penalaran matematis tertera dalam hasil penelitian yang menunjukkan skor. Hal ini sejalan dengan hasil 
penelitian TIM Survey IMSTEP-JICA (Lestari, 2014) di kota Bandung bahwa salah satu kegiatan terkait berpikir kritis yang dianggap sulit oleh siswa untuk mempelajarinya adalah kegiatan pemecahan masalah yang memerlukan penalaran matematis dan menemukan generalisasi atau konjektur.

Agar dapat memberikan penjelasan sederhana dan menyusun strategi dan taktik (strategis and tactics), siswa perlu memiliki wawasan yang luas terhadap matematika. Wawasan yang luas dapat dibangun jika siswa memiliki kemampuan koneksi matematis yang baik.

\section{KESIMPULAN}

Berdasarkan hasil penelitian dan pembahasan yang telah diuraikan di atas, diperoleh kesimpulan bahwa peningkatan kemampuan berpikir kritis matematik siswa yang menggunakan pendekatan Metaphorical Thinking lebih baik daripada siswa yang menggunakan pembelajaran biasa. Selain itu kesulitan siswa dalam menyelesaikan soal-soal kemampuan berpikir kritis matematik terklasifikasi. Temuan lain juga diperoleh pada saat pretes ketuntasan hanya $40 \%$, setelah diadakan penelitian terjadi kenaikan ketuntasan sebesar $30 \%$, sehingga hasil akhir ketuntasan menjadi $70 \%$.

\section{DAFTAR PUSTAKA}

Afrilianto, M. (2012). Peningkatan Pemahaman Konsep dan Kompetensi Strategis Matematis Siswa SMP Dengan Pendekatan Metaphorical Thinking. Jurnal Infinity: Jurnal Ilmiah Program Studi Matematika STKIP Siliwangi Bandung. Vol 1-No 2 : 194-197.

Ahmadi, Y. (2016). Analisis Kemampuan Berpikir Kritis Matematis Siswa pada Materi Segitiga (Penelitian pada SMP Materi Segitiga). Skripsi: UIN Syarif Hidayatullah Jakarta. "in press".

Hendriana, H. (2012). Pembelajaran Matematika Humanis dengan Metaphorical Thinking untuk Meningkatkan Kepercayaan Diri Siswa. Jurnal Infinity: Jurnal Ilmiah Program Studi Matematika STKIP Siliwangi Bandung. Vol 1-No 1 : 95-96.

Hendriana, H. dan Soemarmo, U. (2014). Penilaian Pembelajaran Matematika. Bandung: PT. Refika Aditama

Hendriana, H., Rohaeti, E. E., \& Hidayat, W. (2017). Metaphorical Thinking Learning and Junior High School Teachers' Mathematical Questioning Ability. Journal on Mathematics Education, 8(1), 55-64.

Hendriana, H., Hidayat, W., \& Ristiana, M. G. (2018, January). Student teachers' mathematical questioning and courage in metaphorical thinking learning. In Journal of Physics: Conference Series (Vol. 948, No. 1, p. 012019). IOP Publishing.

Hidayat, W. (2011). Meningkatkan Kemampuan Berpikir Kritis dan Kreatif Matematik Siswa Melalui Pembelajaran Kooperatif Think-Talk-Write (TTW) (Doctoral dissertation, Universitas Pendidikan Indonesia).

Hidayat, W. (2012). Meningkatkan Kemampuan Berpikir Kritis dan Kreatif Matematik Siswa SMA Melalui Pembelajaran Kooperatif Think-Talk-Write (TTW). In Seminar Nasional Penelitian, Pendidikan dan Penerapan MIPA. 
Lestari, K. E. (2014). Implementasi Brain-Based Learning untuk Meningkatkan Kemampuan Koneksi dan Kemampuan Bepikir Kritis serta Motivasi Belajar Siswa SMP. Jurnal Pendidikan UNSIKA: Pendidikan matematika-FKIP UNSIKA. Vol 2-No 1 : 43.

Lestari, K. E. dan Yudhanegara, M. R. (2015). Penelitian Pendidikan Matematika. Bandung. Penerbit: PT. Refika Aditama.

Noto, M. S. (2015). Efektivitas Metakognisi Terhadap Penalaran Matematis pada Mata Kuliah Geometri Transformasi. Jurnal Infinity: Jurnal Ilmiah Program Studi Matematika STKIP Siliwangi Bandung. Vol 4-No $1: 23$

Sumarmo, U., Hidayat, W., Zukarnaen, R., Hamidah, M., \& Sariningsih, R. (2012). Kemampuan dan Disposisi Berpikir Logis, Kritis, dan Kreatif Matematik (Eksperimen terhadap Siswa SMA Menggunakan Pembelajaran Berbasis Masalah dan Strategi Think-Talk-Write). Jurnal Pengajaran MIPA, 17(1), 17-33.

Sumaryati, E. \& Sumarmo, U. (2013). Pendekatan Induktif-Deduktif Disertai Strategi ThinkPair-Square-Share Untuk Meningkatkan Kemampuan Pemahaman dan Berpikir Kritis serta Disposisi Matematis Siswa SMA. Jurnal Infinity: Jurnal Ilmiah Program Studi Matematika STKIP Siliwangi Bandung. Vol 2-No 1 : 30.

Tresnawati, T., Hidayat, W., \& Rohaeti, E. E. (2017). Kemampuan Berpikir Kritis Matematis dan Kepercayaan Diri Siswa SMA. Symmetry: Pasundan Journal of Research in Mathematics Learning and Education, 2(2), 39-45. 